\title{
PENGARUH PEMBERIAN SOAL BERDASARKAN KOMPONEN PISA TERHADAP KECEMASAN BELAJAR MATEMATIKA PADA SISWA KELAS VIII MTSS DARUL MUKHLISIN
}

\author{
Hilda Hakim $^{1}$, Nurul Qomariyah Ahmad ${ }^{2}$, dan Ewis Niati Simahara ${ }^{3}$ \\ ${ }^{1,2}$ STAIN Gajah Putih Takengon, Aceh Tengah, dan ${ }^{3}$ SMPN 12 Aceh Tengah, Aceh \\ Email: hildahakim173@gmail.com, qomariyahnrl@gmail.com, dan uwesniate0702@gmail.com
}

\begin{abstract}
PISA assesses the extent to which students who sit at the end of a primary school have mastered the knowledge and skills necessary to participate as citizens. However, the facts in the field show that the condition of students who are not accustomed to dealing with problems based on the PISA component in school can have psychological effects in the form of anxiety because students assume that questions based on the PISA component are difficult to solve. The purpose of this study was to determine the effect of giving questions based on the PISA component on mathematics learning anxiety in eighth grade students of MTsS Darul Mukhlisin. This research approach is quantitative with a type of causal research, the population is all students of class VIII MTsS Darul Mukhlisin, amounting to 100 students consisting of 4 classes. The sample in this study were all students of VIII class because for a population equal to or less than 100 it should be taken all as a sample. After calculating the coefficient of determination obtained $\mathrm{R}=$ 0.8939 or $89,39 \%$ mathematics learning anxiety is influenced by giving questions based on the PISA component and the remaining $10,61 \%$ is influenced by other factors. From these results it can be seen that students feel anxious because they are unable to solve a problem or problem based on the PISA component so that students experience physical, cognitive, and behavioral symptoms.
\end{abstract}

Keywords: Questions, PISA Components, Mathematics Learning Anxiety.

\begin{abstract}
Abstrak: PISA menilai sejauh mana siswa yang duduk di akhir tahun pendidikan dasar (siswa berusia 15 tahun) telah menguasai pengetahuan dan keterampilan yang penting untuk dapat berpartisipasi sebagai warga negara. Namun, fakta di lapangan menunjukkan bahwa kondisi siswa yang tidak terbiasa menghadapi soal berdasarkan komponen PISA di sekolah dapat mengakibatkan dampak psikologis berupa rasa cemas karena anggapan siswa bahwa soal berdasarkan komponen PISA itu sulit untuk diselesaikan. Adapun tujuan dari penelitian ini adalah untuk mengetahui pengaruh pemberian soal berdasarkan komponen PISA terhadap kecemasan belajar matematika pada siswa kelas VIII MTsS Darul Mukhlisin. Pendekatan penelitian ini adalah kuantitatif dengan jenis penelitian kausal, yang menjadi populasi adalah seluruh siswa kelas VIII MTsS Darul Mukhlisin yang berjumlah 100 siswa yang terdiri dari 4 kelas. Sampel dalam penelitian ini adalah seluruh siswa kelas VIII karena untuk populasi sama dengan atau kurang dari 100 sebaiknya diambil semua sebagai sampel. Setelah dilakukan perhitungan koefisien determinasi diperoleh $\mathrm{R}=0,8939$ atau $89,39 \%$ kecemasan belajar matematika dipengaruhi oleh pemberian soal berdasarkan komponen PISA dan sisanya 10, 61\% dipengaruhi oleh faktor lain. Dari hasil tersebut dapat diketahui bahwa siswa merasa cemas karena tidak mampu menyelesaikan suatu permasalahan atau soal berdasarkan komponen PISA sehingga siswa mengalami gejala fisik, kognitif, dan prilaku.
\end{abstract}

Kata kunci: Soal, Komponen PISA, Kecemasan Belajar Matematika.

\section{PENDAHULUAN}

Proses pendidikan yang baik mengharuskan siswanya dibekali dengan berbagai ilmu pengetahuan, salah satunya tentang ilmu matematika yang dapat membantu siswa dalam mempersiapkan melanjutkan studi dan memecahkan masalah diberbagai situasi, termasuk di sekolah, di rumah, dan di tempat kerja (Turmudi, 2009:1). Banyak ilmu lain 
bergantung dari matematika disebabkan karena matematika merupakan ratunya ilmu atau sumber ilmu. Sebagai contoh, penemuan dan pengembangan teori Mendel dalam biologi melalui konsep probabilitas, teori ekonomi mengenai permintaan dan penawaran yang dikembangkan melalui konsep fungsi dan kalkulus tentang diferensial dan integral, perhitungan pembagian hak waris dalam islam juga menggunakan perhitungan pecahan. Berdasarkan hal tersebut, jelas bahwa matematika itu sangat penting sehingga memberikan peran pada kehidupan sehari-hari maupun dalam perkembangan ilmu dan teknologi.

Berdasarkan urgenitasnya tersebut, matematika menjadi perhatian di dunia internasional dibuktikan dengan adanya asesmen berskala internasional salah satunya PISA (Program for Internasional Student Assessment), yang merupakan program penilaian siswa tingkat internasional tentang literasi membaca, matematika dan sains yang diselenggarakan oleh Organisation for Economic Cooperation and Development (OECD) atau organisasi untuk kerjasama ekonomi dan pembangunan yang dilaksanakan pada setiap periode selama 3 tahun sekali. PISA menilai sejauh mana siswa yang duduk di akhir tahun pendidikan dasar (siswa berusia 15 tahun) telah menguasai pengetahuan dan keterampilan yang penting untuk dapat berpartisipasi sebagai warga negara untuk anggota masyarakat yang membangun dan bertanggung jawab (Purnomo, Suryo dan Dafik, 2015:1155). PISA memiliki tiga komponen yaitu konten, proses, dan konteks sebagai identifikasi dari soal berdasarkan komponen PISA itu sendiri.

Indonesia telah berpartisipasi dalam PISA sejak tahun 2003, namun pencapaian prestasi Indonesia pada studi PISA masih jauh dari predikat memuaskan, dimana skala yang harus dicapai dalam studi PISA adalah 0-800. Pada tahun 2006 Indonesia mendapat peringkat 52 dari 57, pada tahun 2009 peringkat 61 dari 65 kondisi ini terus mengalami penurunan hingga pada tahun 2012 Indonesia mendapat peringkat 64 dari 65 negara (Wardan, Sri dan Rumiati, 2011:26). Berdasarkan dari penelitian yang dilakukan oleh (Charmila, Ninik dkk, 2016:198) didapatkan soal berdasarkan komponen PISA dikembangkan dengan tujuan untuk mengaktifkan kemampuan bernalar siswa dan diketahui bahwa siswa merasa tertarik, termotivasi, dan tertantang untuk menyelesaikan soal.

Agar perolehan peringkat pada PISA dapat lebih baik maka siswa SMP harus terbiasa dengan pemberian soal berdasarkan komponen PISA di sekolah, salah satunya pada siswa kelas VIII telah mempelajari komponen, konten berupa ruang dan bentuk, 
perubahan dan keterkaitan, dan kuantitas atau bilangan yang menggunakan komponen proses berupa mampu merumuskan masalah secara matematis dan mampu menggunakan konsep, fakta, prosedur, serta penalaran dalam matematika, dengan komponen konteks pribadi, sosial dan ilmu pengetahuan. Menurut Piagget seperti yang dikutip oleh (Suherman, E, 2003:43), bahwa mulai usia 11 tahun (tahap operasi formal) anak mampu melakukan penalaran dengan menggunakan hal-hal abstrak, kemampuan untuk menyusun serangkaian hipotesis dan mengujinya serta kemampuan menyusun kombinasi-kombinasi yang mungkin dari unsur-unsur dalam suatu sistem sehingga sudah mampu mentransformasikan tiga komponen PISA yaitu konten, proses dan konteks. Akan tetapi, kondisi siswa yang sebelumnya tidak pernah mendapat soal berdasarkan komponen PISA di sekolah akan mengakibatkan dampak psikologis berupa rasa cemas karena anggapan siswa bahwa soal berdasarkan komponen PISA itu sulit untuk diselesaikan. Bila hal ini terjadi, maka akan berakibat pada pencapaian hasil pekerjaan menyelesaikan soal berdasarkan komponen PISA.

Menurut Priest seperti yang dikutip oleh (Maisaroh dan Falasifatul, 2011:80), kecemasan adalah perasaan yang dialami seseorang ketika berpikir bahwa sesuatu yang tidak menyenangkan akan terjadi, menimbulkan ketakutan, ketidakpastian, bingung atau merasa takut akan kesalahan. Kecemasan merupakan ketakutan seseorang terhadap sesuatu yang dianggap mengancam dirinya sebagai contoh pada pengerjaan soal matematika siswa dapat merasa cemas dikarenakan siswa takut akan hasil yang dicapai nantinya tidak memuaskan. Tobias seperti yang dikutip oleh (Masruroh, 2015:180), yang mendefinisikan kecemasan matematika sebagai perasaan-perasaan tegang dan cemas yang mencampuri manipulasi bilangan-bilangan serta pemecahan masalah matematis dalam beragam situasi akademik maupun kehidupan sehari-hari. Siswa yang mengalami kecemasan terhadap matematika merasa bahwa dirinya tidak mampu dan tidak bisa mempelajari materi matematika dan mengerjakan soal-soal. (Suci dan Yoppy, 2016:48), mengadakan penelitian yang hasilnya didapatkan siswa yang memiliki konsepsi bahwa penilaian yang dilakukan guru sebagai sebuah cara untuk membandingkan performannya dengan kriteria-kriteria eksternal, maka secara signifikan berhubungan terhadap peningkatan kecemasan matematika.

Dari penjelasan tersebut dapat diketahui bahwa kecemasan matematika merupakan ketakutan siswa dalam mengerjakan soal berdasarkan komponen matematika di sekolah menengah terutama di SMP tentunya siswa merasa khawatir ketika mengerjakan soal 
berdasarkan komponen PISA yang memiliki level yang berbeda dengan soal dari sekolah. Agar hal ini terbukti maka diperlukan penelitian lebih lanjut dengan subjek penelitiannya siswa kelas VIII MTSs Darul Mukhlisin Aceh Tengah, karena belum pernah mengerjakan soal berdasarkan komponen PISA. Tujuan dari penelitian ini adalah mengetahui pengaruh pemberian soal berdasarkan komponen PISA terhadap kecemasan belajar matematika pada siswa kelas VIII MTsS Darul Mukhlisin.

\section{LANDASAN TEORI}

\section{Kecemasan Belajar Matematika Siswa}

Matematika dikaitkan dengan simbol yang terdapat pada rumus-rumus yang pada sebagian siswa menganggapnya sebagai hal sulit yang dapat mengakibatkan rasa cemas. Taylor seperti yang dikutip oleh (Anita, 2004:127), mengemukakan bahwa kecemasan merupakan suatu perasaan subyektif mengenai ketegangan mental yang menggelisahkan sebagai reaksi umum dari ketidakmampuan mengatasi suatu masalah atau tidak adanya rasa aman. Ketika siswa merasa tegang atau tidak aman siswa akan sulit untuk menyelesaikan permasalahan terutama pada matematika. Siswa yang mengalami kecemasan terhadap matematika merasa bahwa dirinya tidak mampu dan tidak bisa mempelajari materi dan mengerjakan soal matematika. Richardson dan Suinn dalam Masruroh menyatakan bahwa kecemasan matematika melibatkan perasaan tegang dan cemas mempengaruhi berbagai cara ketika menyelesaikan soal matematika dalam kehidupan nyata dan akademik (Masruroh, 2015:180). Lebih lanjut mereka menjelaskan kecemasan siswa pada matematika merupakan bentuk perasaan siswa berupa perasaan gelisah, khawatir ataupun takut dalam menghadapi persoalan matematika baik pada saat pembelajaran matematika maupun pada saat tes dengan berbagai bentuk gejala yang ditimbulkan (Masruroh, 2015:180). Kecemasan matematika merupakan rasa takut siswa terhadap pemberian dan penyelesaian soal matematika yang dicampuri dengan manipulasi bilangan-bilangan sehingga mengakibatkan perasaan cemas pada diri siswa.

Tekanan sosial yang membentuk kecemasan matematika dapat berasal dari situasi atau kondisi di mana siswa "dituntut" harus mendapatkan nilai atau skor yang tinggi dan harus mencapai kriteria standarisasi eksternal yang telah ditetapkan, sehingga mereka takut terhadap masalah yang diakibatkan jika mereka gagal melaluinya. Hal ini sebagaimana yang diungkapkan oleh (Suci dan Yoppy, 2016:49-50), bahwa "penilaian yang dipandang sebagai cara pemberian skor dengan tes beresiko tinggi (high-stake 
testing) memberikan dampak yang tidak menguntungkan, salah satu di antaranya adalah mendorong kecemasan berlebih".

Kecemasan belajar matematika siswa adalah adanya perubahan tingkah laku, sikap menyangkut ilmu pengetahuan siswa yang dipengaruhi rasa takut, khawatir, dan cemas siswa terhadap hal-hal yang terkait dengan matematika baik berupa simbol matematika atau pada soal berdasarkan komponen matematika yang diberikan dalam proses pencarian pengetahuan dan keterampilan bagi siswa. Adapun kecemasan menurut (Munaisah, 2015:225), ini dipengaruhi oleh beberapa gejala yaitu: fisik, kognitif dan prilaku. Berdasarkan uraian di atas, maka kecemasan matematika siswa yang dimaksud dalam penelitian ini adalah sikap atau reaksi emosional yang ditunjukkan ataupun di rasakan siswa saat mengikuti pembelajaran atau berinteraksi dengan matematika yang dipengaruhi oleh faktor lingkungan dan personal.

\section{Soal Berdasarkan Komponen PISA}

Sebagai salah satu asesmen berskala internasional PISA merupakan salah satu agen yang akan menilai sejauh mana anak yang berumur 15 tahun atau siswa kelas VIII sekolah menengah telah menguasai pemahamannya dan keterampilannya tentang matematika itu sendiri. Hal-hal yang dinilai dalam studi PISA meliputi literasi matematika, literasi membaca dan literasi sains. Untuk mentransformasi prinsip-prinsip literasi di atas, tiga komponen besar di identifikasi pada studi PISA, yaitu konten, proses dan konteks. Komponen konten dalam studi PISA dimaknai sebagai isi atau materi atau subjek matematika yang dipelajari disekolah. Materi yang diujikan dalam komponen konten berdasarkan PISA meliputi perubahan dan keterkaitan (change and relationship), ruang dan bentuk (space and shape), kuantitas (quantity), dan ketidakpastian data (uncertainty and data). Untuk menyelesaikan konten tersebut yang disajikan dalam bentuk permasalahan siswa menggunakan komponen proses.

Komponen proses dalam studi PISA dimaknai sebagai serangkaian cara atau langkah-langkah seseorang untuk menyelesaikan suatu permasalahan pada konten dalam situasi atau konteks tertentu dengan menggunakan matematika sebagai alat sehingga permasalahan itu dapat diselesaikan. Kemampuan proses didefinisikan sebagai kemampuan seseorang dalam merumuskan (formulate), menggunakan (employ) dan menafsirkan (interpret) matematika untuk memecahkan masalah.

Selanjutnya kerangka penilaian literasi matematik menurut (Wardan, S dan Rumiati, 2011:14-17), menyebutkan bahwa kemampuan proses melibatkan tujuh hal 
penting sebagai berikut: a. Communication, b. Mathematising, c. Representation, d. Reasoning and Argument, e. Devising Strategies for Solving Problems, f. Using Symbolic, Formal and Technical Language and Operation, g. Using Mathematics Tools.

Komponen ketiga yang diidentifikasi dalam studi PISA adalah komponen konteks. Komponen konteks dalam studi PISA dimaknai sebagai situasi yang tergambar dalam suatu permasalahan. Ada empat konteks yang menjadi fokus, yaitu: konteks pribadi (personal), konteks pekerjaan (occupational), konteks sosial (social) dan konteks ilmu pengetahuan (scientific) (Wardan, S dan Rumiati, 2011:15).

Berdasarkan penjelasan di atas, untuk siswa SMP kelas VIII untuk komponen konten yang diujikan berupa:

a. Perubahan dan keterkaitan, berkaitan dengan pokok pelajaran aljabar.

b. Ruang dan bentuk, berkaitan dengan pokok pelajaran geometri.

c. Kuantitas (bilangan), berkaitan dengan hubungan bilangan dan pola bilangan.

Dalam pengerjaan komponen konten di atas siswa juga melalui langkah-langkah dalam menyelesaian soal berdasarkan komponen PISA dengan melalui komponen proses, berdasarkan teori Piaget siswa kelas VIII komponen proses yang diujikan yaitu:

a. Mampu merumuskan masalah, siswa diminta untuk mengulang atau menyalin informasi yang diperoleh sebelumnya.

b. Mampu menggunakan konsep, fakta, prosedur, dan penalaran dalam matematika.

Selain kedua komponen tersebut, dalam pemberian soal berdasarkan komponen PISA komponen konteks juga dimaknai sebagai situasi yang tergambar dalam suatu permasalahan yang meliputi: pribadi, sosial dan ilmu pengetahuan.

Soal-soal matematika dalam studi PISA lebih banyak mengukur kemampuan menalar, pemecahan masalah, berargumentasi dan pemecahan masalah dari pada soalsoal berdasarkan komponenyang mengukur kemampuan teknis baku yang berkaitan dengan ingatan dan perhitungan semata. Berikut ini disajikan contoh soal berdasarkan komponendiujikan dalam PISA 2009 berdasarkan tulisan (Wardan, S dan Rumiati, 2011:19):

Sebuah kelas ingin menyewa bis untuk piknik. Ada tiga perusahaan yang dihubungi. Perusahaan A menyewakan bis dengan harga awal 375 zed dan setiap bertambah 1 kilometer harga bertambah 0, 5 zed. Perusahaan B menyewakan dengan harga awal 250 zed dan setiap bertambah 1 kilometer harga bertambah 0,75 zed. Perusahaan $\mathrm{C}$ menyewakan dengan harga tetap yaitu 350 zed untuk jarak maksimum 200 kilometer dan 1,02 per kilometer untuk jarak di atas 200 kilometer. Jika jarak tempat-tempat yang dikunjungi 
antara 400 sampai 600 kilometer, bis dari perusahaan manakah yang sebaiknya disewa?

Persoalan di atas bertemakan piknik sekolah, persoalan tersebut berakar dari permasalahan sehari-hari dalam konteks sosial, dan konten yang diuji adalah perubahan dan keterkaitan, proses matematika yang diuji meliputi kemampuan untuk merumuskan suatu hubungan, persamaan dan pertidaksamaan. Karena jarak tempat yang dikunjungi tidak ditentukan dengan pasti, maka soal berdasarkan komponen tersebut juga menguji kemampuan siswa untuk melakukan perkiraan dan mempertimbangkan ketidakpastian.

Berdasarkan penjelasan di atas, dapat disimpulkan bahwa soal berdasarkan komponen PISA merupakan soal matematika bertaraf internasional yang diujikan kepada siswa sekolah menengah khususnya kelas VIII untuk menilai sejauh mana pengetahuan dan keterampilan mereka berdasarkan tiga komponen yaitu: komponen konten atau materi yang dipelajari disekolah mencakup perubahan dan keterkaitan, ruang dan bentuk, serta kuantitas (bilangan), kemudian komponen proses atau cara untuk menyelesaikan permasalahan, mencakup mampu merumuskan masalah dan mampu menggunakan konsep, fakta, prosedur, dan penalaran dalam matematika serta komponen konteks atau situasi yang digambarkan dalam permasalahan, mencakup pribadi, sosial, ilmu pengetahuan.

\section{METODE PENELITIAN}

Penelitian ini menggunakan pendekatan kuantitatif, jenis kausal karena ingin mengetahui sebab akibat antara pemberian soal berdasarkan komponen PISA dengan kecemasan. Waktu penelitian dilakukan pada tahun 2017 dimana tempat penelitiannya Madrasah Tsanawiyah Swasta Darul Mukhlisin Aceh Tengah. Populasi pada penelitian ini adalah kelas VIII MTsS Darul Mukhlisin yang berjumlah 4 kelas yang terdiri dari 2 kelas putri dan 2 kelas putra dengan jumlah 100 siswa. Menurut (Arikunto, 2013:134), apabila jumlah populasi 100 maka keseluruhannya dijadikan sampel. Instrumen yang digunakan adalah non tes berupa angket kecemasan matematis siswa dan tes berupa soal berdasarkan komponen PISA. Instrumen angket tersebut diukur validitas dan realibilitasnya. Bedasarkan pengukuran tersebut didapatkan validitas konstruknya yang telah divalidasi oleh pakar psikologi dan matematika ada beberapa butir pernyataan yang di harus diperbaiki dari segi keterkaitan dengan indikator dan bahasa, validitas empirisnya dihitung menggunakan product moment, dimana dari 52 butir pernyataan yang dibuat didapatkan 32 butir valid dan 20 butir tidak valid sedangkan untuk 
reliabilitasnya menggunakan alpha cronbach didapatkan 0,91 dengan kategori tinggi, sehingga untuk penelitian digunakan 32 butir pernyataan. Untuk soal berdasarkan komponen PISA mengambil yang sudah baku, tetapi karena berbahasa Inggris maka harus diterjemahkan ke dalam bahasa Indonesia, untuk itu hanya perlu validitas konstruk dilihat dari segi bahasa yang divalidasi oleh pakar matematika, hasilnya sudah bagus dan dapat digunakan. Teknik analisis datanya menggunakan uji prasyarat berupa uji normalitas dan homogenitas, sedangkan uji hipotesisnya menggunakan regresi.

\section{HASIL DAN PEMBAHASAN}

\section{A. Hasil Penelitian}

Data hasil tes pemberian soal berdasarkan komponenPISA dan angket kecemasan belajar matematika dapat dilihat pada tabel 1 berikut.

Tabel 1 Hasil Pengolahan Data Soal Berdasarkan Komponen PISA dan Angket Kecemasan Belajar Matematika

\begin{tabular}{lcc}
\hline Analisis & $\begin{array}{c}\text { Soal berdasarkan } \\
\text { komponenPISA }\end{array}$ & Kecemasan \\
\hline N (sampel) & 100 & 100 \\
Rata-rata & 40 & 99 \\
Skor Tertinggi & 68 & 135 \\
Skor Terendah & 9 & 59 \\
\hline
\end{tabular}

Berdasarkan tabel 1 menunjukkan bahwa rata-rata skor soal berdasarkan komponen PISA siswa yaitu 40 dengan skor tertinggi 68 dan skor terendah 9 sedangkan rata-rata hasil angket kecemasan belajar matematika siswa yaitu 99 dengan skor tertinggi kecemasan belajar matematika siswa 135 dan skor terendah 59 .

\section{Hasil Uji Prasyarat}

\section{a. Uji Normalitas Data}

Pengujian normalitas data digunakan Uji Kolmogorov-Smirnov dengan mengunakan taraf signifikansi 0,05 dengan bantuan SPSS 16. Kriteria pengujiannya:

$\mathrm{D}_{\mathrm{o}} \leq \mathrm{D}$-tabel maka $\mathrm{H}_{0}$ diterima

$\mathrm{D}_{\mathrm{o}}>\mathrm{D}$-tabel maka $\mathrm{H}_{0}$ ditolak 
Tabel 2 Tests of Normality

\begin{tabular}{lccc}
\hline & \multicolumn{3}{c}{ Kolmogorov-Smirnov } \\
& Statistic & Df & Sig. \\
\hline Hasil Kecemasan & .088 & 100 & .055 \\
a. Lilliefors Significance Correction & &
\end{tabular}

Berdasarkan Tabel 2 diperoleh $\mathrm{D}_{\mathrm{o}}=0,088$. Sedangkan dari tabel pada $\propto=0,05$ (df $=100$ ), diperoleh D-tabel $=0,122$. Ini berarti Do lebih kecil dari D-tabel. Dengan demikian $\mathrm{H}_{0}$ diterima atau data sampel berasal dari populasi berdistribusi normal.

\section{b. Uji Homogenitas Data}

Pengujian homogenitas pada penelitian ini menggunakan uji homogenitas Lavene dengan berbantuan SPSS 16. Kriteria pengujiannya, apabila taraf signifikasinya $>0,05$ maka data homogen dan bila $\leq 0,05$ maka data tidak homogen.

Tabel 3 Test of Homogeneity of Variances

\begin{tabular}{cccc} 
Levene Statistic & $\mathrm{df1}$ & $\mathrm{df2}$ & Sig. \\
1.695 & 25 & 54 & .053 \\
\hline
\end{tabular}

Berdasarkan Tabel 3, diperoleh taraf signifikansi 0,053 lebih besar dari 0,05 maka data homogen.

\section{Uji Hipotesis}

Uji hipotesis yang dilakukan dalam penelitian ini yaitu dengan menggunakan regresi untuk menguji apakah terdapat pengaruh antara pemberian soal berdasarkan komponen PISA terhadap kecemasan belajar matematika pada siswa dikelas VIII. Berdasarkan hasil perhitungan regresi, dengan persamaan regresi $\hat{y}=-1,9257+2,5231 \mathrm{x}$, walaupun koefisien regresi a bernilai negatif, hal tersebut tidak menjadi persoalan karena koefisien regresi yang mempengaruhi nilai taksiran adalah koefisien regresi b (Irianto, 2006:162). Untuk menjelaskan dan mengambil kesimpulan mengenai pengaruh pemberian soal berdasarkan komponen PISA (X) terhadap kecemasan belajar matematika siswa (Y). Persamaan ini memiliki arti setiap kenaikan satu unit pemberian soal berdasarkan komponen PISA akan meningkatkan 2,5231 unit kecemasan belajar matematika siswa dengan konstanta $-1,9257$. Untuk melihat pengaruh pemberian soal 
berdasarkan komponen PISA terhadap kecemasan belajar matematika siswa di kelas VIII MTsS Darul Mukhlisin dengan kriteria pengujian:

Jika $\mathrm{F}_{\text {hitung }}>\mathrm{F}_{\text {tabel }}$, maka Ha diterima pada $\alpha=0,05$

$\mathrm{F}_{\text {hitung }} \leq \mathrm{F}_{\text {tabel, }}$ maka Ha ditolak pada $\alpha=0,05$.

Berdasarkan hasil pengujian yang terlampir diperoleh bahwa $\mathrm{F}_{\text {hitung }}(\mathrm{b} / \mathrm{a})=9,6875$ lebih besar dari $\mathrm{F}_{\text {tabel }}=3,94$ hal ini berarti $\mathrm{H}_{\mathrm{a}}$ diterima pada taraf signifikan $\alpha=0,05$ dengan demikian regresi $\mathrm{y}$ atas $\mathrm{x}$ adalah berarti atau signifikan kesimpulan dari hasil pengujian linieritas dan signifikansi regresi yaitu terdapat pengaruh antara pengaruh pemberian soal berdasarkan komponen PISA terhadap kecemasan belajar matematika pada siswa kelas VIII MTsS Darul Mukhlisin.

Setelah dilakukan perhitungan koefisien determinasi $\mathrm{R}=r^{2}$ yang merupakan suatu ukuran untuk menunjukkan pengaruh variabel X (pemberian soal berdasarkan komponen PISA) yang mempunyai linier terhadap variabel Y (kecemasan belajar matematika siswa dapat diketahui dari nilai koefisien determinsi $r^{2}$.

Berdasarkan perhitungan $r_{x y}=0,9485$, sehingga nilai koefisien determinasi $\mathrm{R}=r^{2}$ adalah $\mathrm{R}=0,8939$ dan berdasarkan ketentuan perhitungan diperoleh kesimpulan bahwa pemberian soal berdasarkan komponenPISA mempengaruhi kecemasan belajar matematika siswa sebesar 0, 8939 atau 89,39\% dan sisanya sebesar 10,61\% disebabkan oleh faktor lain.

\section{B. Pembahasan}

Penelitian ini bertujuan untuk menguji hipotesis yang berbunyi terdapat pengaruh pemberian soal berdasarkan komponen PISA terhadap kecemasan belajar matematika siswa di kelas VIII MTsS Darul Mukhlisin melalui pendekatan kuantitatif dan dengan menggunakan jenis penelitian regresi, peneliti berusaha menjawab hipotesis tersebut. Untuk mendapatkan hasil penelitian ini yang merupakan jawaban dari hipotesis tersebut, peneliti memberikan soal berdasarkan komponen PISA dan angket kepada siswa kelas VIII yang bertujuan untuk mengetahui pengaruh pemberian soal berdasarkan komponen PISA terhadap kecemasan belajar matematika siswa di kelas VIII MTsS Darul Mukhlisin. Setelah seluruh data yang dibutuhkan dalam penelitian ini terkumpul, maka untuk mendapatkan hasil penelitian ini peneliti menggunakan teknik analisa data dengan menerapkan uji Regresi. 
Berdasarkan hasil penelitian dengan persamaan regresi $\hat{y}=-1,9257+2,5231 \mathrm{x}$, dan nilai $F_{\text {hitung }}>F_{\text {Tabel }}$ yakni 9,6875 > 3,94 maka Ho ditolak dan Ha diterima dan berdasarkan perhitungan $r_{x y}=0,9485$, sehingga nilai koefisien determinasi $\mathrm{R}=r^{2}$ adalah $\mathrm{R}=0,8939$ yang memiliki arti bahwa pemberian soal berdasarkan komponen PISA mempengaruhi kecemasan belajar matematika siswa di kelas VIII MTsS Darul Mukhlisin sebesar 0, 8939 atau 89,39\% dan sisanya sebesar 10,61\% disebabkan oleh faktor lain. Hal tersebut ditunjukkan pada gambar 1 berikut.

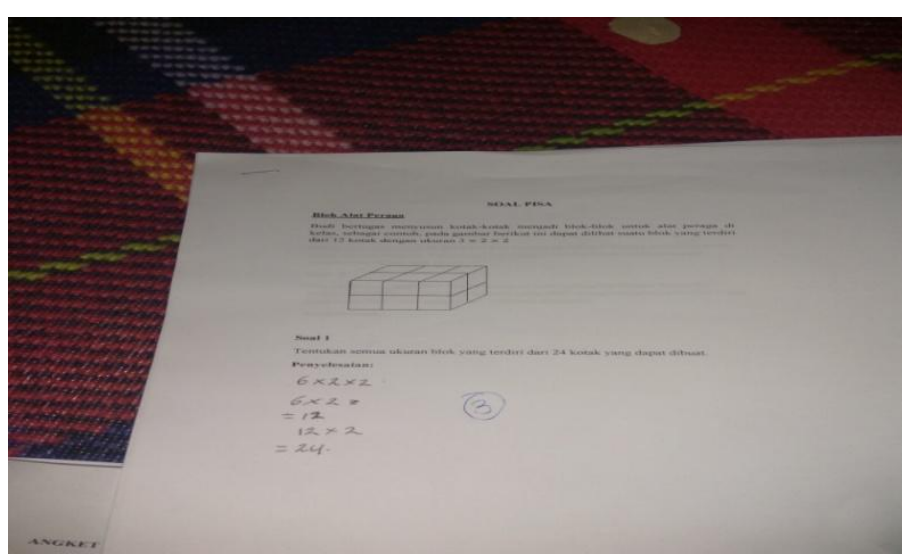

Gambar 1 Jawaban Soal berdasarkan komponen PISA siswa

Berdasarkan Gambar 1 menunjukkan bahwa siswa tidak dapat menyelesaikan soal berdasarkan komponen PISA disebabkan karena siswa merasa cemas berupa siswa merasa gelisah, khawatir, bimbang dengan jawaban matematika, dan takut yang timbul karena anggapan siswa bahwa soal berdasarkan komponen PISA itu sulit. Hal ini sejalan dengan hasil penelitian (Simalango dkk, 2018: 43) yaitu siswa mengalami kesulitan dalam menyelesaikan soal PISA karena sulit memahami soal dan mengubah permasahan nyata ke dalam bentuk matematika. Selain itu penyelesaiannya membutuhkan tingkat penalaran lebih tinggi dari yang biasanya, tidak terbiasanya mengerjakan, rasa takut siswa terhadap soal matematika, rasa tidak senang terhadap mata pelajaran matematika, tidak dapat menyelesaikan dalam waktu yang diberikan serta rasa khawatir hasil yang dicapai tidak memuaskan. Hal tersebut dibuktikan dengan sebagian siswa mengosongkan jawaban PISA nya dengan rincian: soal no 1 dikosongkan oleh 5 siswa, no. 2 dikosongkan oleh 28 siswa, no.3 dikosongkan oleh 16 siswa, no.4 dikosongkan oleh 17 siswa, no.5 dikosongkan oleh 14 siswa dan no.6 dikosongkan oleh 43 siswa. Pengisian angket oleh siswa memperkuat hasil penelitian, seperti yang ditunjukkan pada gambar 2 berikut: 


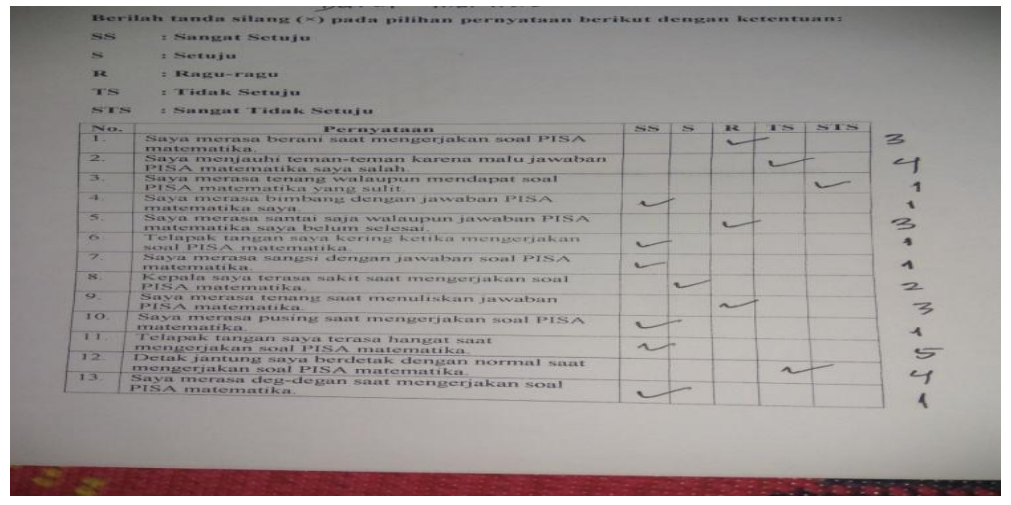

Gambar 2 Jawaban Angket Kecemasan Belajar Matematika Siswa

Gambar di atas menunjukkan bahwa dari angket kecemasan tersebut terlihat siswa merasa cemas karena tidak mampu menyelesaikan suatu permasalahan sehingga siswa mengalami gejala fisik, kognitif, dan prilaku dengan indikatornya masing-masing diperoleh 37 siswa merasa tegang, 41 siswa merasa gugup, 32 siswa berkeringat, 36 siswa gemetar, 38 siswa dengan detak jantung meningkat, 39 siswa sakit kepala, 36 siswa kurang percaya diri, 38 siswa dengan keraguan diri, 38 siswa berdiam diri, 30 siswa menghindari pelajaran matematika, 30 siswa mengalami gangguan tidur, dan 32 siswa dengan nafsu makan berkurang, dimana Munasiah menjelaskan perasaan cemas timbul ketika seseorang mengalami tekanan perasaan (frustasi) serta ketidakmampuan menghadapi masalah. Menurut (Munaisah, 2015:229), perasaan cemas biasanya diikuti oleh reaksi fisiologis tertentu yaitu seperti perubahan detak jantung dan pernapasan. Jadi, ketika siswa diberikan soal berdasarkan komponen PISA, hal tersebut menjadi suatu permasalahan yang tidak pernah dihadapi sebelumnya oleh siswa khususnya di kelas VIII MTsS Darul Mukhlisin sehingga siswa merasa tidak mampu untuk menyelesaikan soal berdasarkan komponen tersebut dan timbul perasaan cemas dari dalam diri siswa yang berakibat pada penyelesaiannya. Hal tersebut dibuktikan dengan hasil observasi yang dilakukan bahwa siswa terlihat gugup, bingung, khawatir, banyak bertanya kepada teman mengenai jawaban soal, sering bertanya berapa lama waktu pengerjaan akan habis, dan banyak siswa yang meminta izin keluar untuk buang air, serta siswa banyak melakukan gerakan-gerakan tidak berguna seperti menjatuhkan pulpen ke lantai, melihat ke atap dan sebagainya. Sedangkan berdasarkan hasil wawancara kecemasan belajar matematika siswa juga dipengaruhi oleh faktor lain seperti tidak adanya motivasi belajar siswa, disiplin belajar, tingkat intelegensi dan tidak tertarik mengerjakan soal, serta rasa tidak suka siswa terhadap guru pelajaran matematika. Maka dapat disimpulkan bahwa kecemasan belajar matematika siswa dapat dipengaruhi oleh pemberian soal berdasarkan 
komponen PISA yang dianggap sebagai suatu ancaman bagi diri siswa karena takut hasil jawaban soal berdasarkan komponen PISA tidak memuaskan.

\section{KESIMPULAN}

Berdasarkan hasil penelitian, dapat diperoleh kesimpulan sebagai berikut: terdapat pengaruh pemberian soal berdasarkan komponen PISA terhadap kecemasan belajar matematika siswa di kelas VIII MTsS Darul Mukhlisin, berdasarkan perhitungan uji hipotesis didapatkan persamaan regresi $\hat{y}=-1,9257+2,5231$ x dengan pengujian linieritas dan signifikansi regresi diperoleh $F_{\text {hitung }}>F_{\text {Tabel }}$ yakni 9,6875 $>3,94$, hal ini berarti $\mathrm{H}_{\mathrm{a}}$ diterima pada taraf signifikan $\alpha=0,05$ dengan demikian regresi y atas $\mathrm{x}$ adalah berarti atau signifikan, dan terdapat pengaruh pemberian soal berdasarkan komponen PISA terhadap kecemasan belajar matematika siswa di kelas VIII MTsS Darul Mukhlisin. Kemudian dilanjutkan dengan perhitungan koefisien determinasi, diperoleh $\mathrm{R}=$ 0,8939 atau 89,39\% kecemasan belajar matematika dipengaruhi oleh pemberian soal berdasarkan komponen PISA dan sisanya 10,61\% dipengaruhi oleh faktor lain.

\section{DAFTAR PUSTAKA}

Anita, Ika Wahyu. (2004). "Pengaruh Kecemasan Matematika (Matematiics Anxiety) terhadap Kemampuan Koneksi Matematis Siswa SMP”. Jurnal Ilmiah Matematika STKIP Siliwangi Bandung. vol 3, No.1 Februari.

Arikunto, Suharsimi.(2013). Prosedur Penelitian Suatu Pendekatan Praktik. Jakarta: Rineka Cipta.

Charmila, Ninik, Zulkardi, dan Darmawijoyo. (2016). "Pengembangan Soal berdasarkan komponen Matematika Model PISA Menggunakan Konteks Jambi”. Jurnal Penelitian dan Pendidikan. Universitas Sriwijaya. Vol. 20. No 2. Desember.

Irianto, Agus. (2004). "Statistik Konsep Dasar, Aplikasi, dan Pengembangannya". Jakarta: Kencana Prenada Media Grup.

Maisaroh, Eka Nur dan Falasifatul Falah. (2011). "Religius dan Kecemasan Menghadapi Ujian Nasional pada Siswa Madrasah Aliyah”. Jurnal Proyeksi. Vol.6 (2). ISSN:1967-845

Masruroh, Laili. (2015). "Pengaruh Kecemasan Siswa pada Matematika terhadap Hasil Belajar Matematika di SMP”. Jurnal Pendidikan Matematika STKIP PGRI Sidoarjo, Vol 3, No. 2, September. ISSN: 2337-8166. 
Munasiah. (2015). "Pengaruh Kecemasan Belajar dan Pemahaman Konsep Matematika Siswa terhadap Kemampuan Penalaran Matematika". Jurnal Formatif 5 (3).

Purnomo, Suryo dan Dafik. (2015). "Analisis Respon Siswa tehadap Soal berdasarkan komponenPISA Konten Shape and Space dengan Rasch Model”, Seminar Nasional Matematika dan Pendidikan Matematika UNY. ISBN. 978-62-73403$0-5$.

Simalango, Maria M, Darmawijoyo dan Nyimas Aisyah. (2018). "Kesulitan Siswa dalam Menyelesaikan Soal-Soal PISA Pada Konten Change and Relationship Level 4, 5, dan 6 di SMPN 1 Indralaya”. Jurnal Pendidikan Matematika. Vol. 12. No.1.

Suci, Veni Wulan dan Yoppy Wahyu Purnomo. (2016). "Hubungan antara Konsepsi Penilaian dan Kecemasan Siswa Sekolah dasar dikelas Matematika”. Jurnal IAIN Mataram Vol.9.No.1 Mei.

Suherman, Erman dkk. (2003). Strategi Pembelajaran Matematika Kontemporer. Bandung: Universitas Pendidikan Indonesia.

Turmudi. (2009). Taktik dan Strategi Pembelajaran Matematika. Jakarta: Leuser Cita Pustaka.

Wardan, Sri dan Rumiati. (2011). Modul: Istrumen Penilaian Hasil Belajar Matematika SMP Belajar dari PISA dan TIMSS. Jakarta: Kementrien Pendidikan Nasional. 